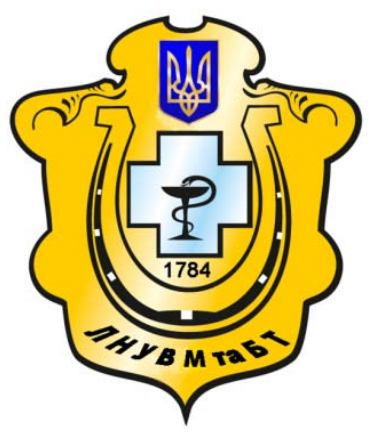

Науковий вісник Львівського національного університету ветеринарної медицини та біотехнологій імені С.3. Гжицького

Scientific Messenger of Lviv National University of Veterinary Medicine and Biotechnologies named after S.Z. Gzhytskyj

doi:10.15421/nvlvet7012

ISSN 2413-5550 print

ISSN 2518-1327 online

$\underline{\text { http://nvlvet.com.ua/ }}$

УДК 577.15:616.13-004.6

\title{
Вплив продуктів окиснення естерів холестеролу на розвиток атеросклерозу
}

\author{
Т.М. Гривул, С.М. Верес, Є.М. Макух \\ grytheo@gmail.com
}

\begin{abstract}
Львівський наџіональний університет ветеринарної медицини та біотехнологій імені С.3. Гжицького, вул. Пекарська, 50, м. Львів, 79010, Україна
\end{abstract}

\begin{abstract}
Продукти пероксидного окиснення ліпідів утворюються у місиях зростання оксидативного стресу, а їх накопичення призводить до виникнення атеротичних пошкоджень. Більшість проведених дотепер досліджень присвячені утворенню та метаболізмові окиснених ліпідів, але даних про їх біологічну активність і можливі патофізіологічні функиії $є$ небагато. $B$ даному огляді зроблено спробу проаналізувати механізми утворення, метаболічну активність та шляхи перетворення естерів холестеролу, які містять ненасичені жирні кислоти, що можуть окиснюватися з утворенням пероксидів. Останні здатні відновлюватися до відповідних спиртів, які можуть окиснюватися до біологічно-активних альдегідів, що вносятиь значний вклад у розвиток прогресуючих атеросклеротичних пошкоджень.

Найбільше естерів холестеролу є у складі $\beta$-ліпопротеїнів, і хоча локалізовані вони у гідрофобному ядрі, але здатні окиснюватися до гідропероксидів швидше, ніж фосфоліпіди зовнішнього шару. Більшість альдегідів, які утворюються при пероксидаиії естерів холестеролу - ие дев'яти-, восьми- $i$ п'ятикарбонові сполуки. Оскільки естери холестеролу у $\beta$ ліпопротеїнах утворені переважно лінолевою кислотою, тому ї̈ рівень виявився надійним тестом ступеня пероксидачії uии естерів.

Аналіз стереоізомерів окиснених ліпідів, які були виділені із атерогенних бляшок, засвідчив значний вклад ензиму ліпооксигенази в оксидативну модифікаиію естерів холестеролу. Важливу роль у метаболізмі гідроксидів естерів холестеролу відіграють і селенвмісні ензими, зокрема: глютатіонпероксидаза і тіоредоксинредуктаза. Отримані також переконливі дані про участь у цих проиесах і альдозоредуктази.

Естери холестеролу гальмують мітотичну активність фактора росту атерогенних блямок, фактор росту фібробластів і $\beta 1$-антипроліферативну активність трансформуючого фактора росту.

Отже, оксидативна модифікація ліпідів взагалі, та окиснених естерів холестеролу зокрема, є однією з причин розвитку прогресуючих атеросклеротичних пошкоджень, хоча метаболічний шлях від ліпопротеїнових частинок до атеросклеротичної бляшки вивчений недостатньо.
\end{abstract}

Ключові слова: оксидачія ліпідів, пероксидація естерів холестеролу, запалення, атеросклероз.

\section{Влияние продуктов окисления эфиров холестерола на развитие атеросклероза}

\author{
Т.Н. Гривул, Е.Н. Верес, Е.М. Макух \\ grytheo@gmail.com
}

\begin{abstract}
Львовский национальный университет ветеринарной медицины и биотехнологий имени С.3. Гжицкого, ул. Пекарская, 50, г. Львов, 79010, Украина
\end{abstract}

\begin{abstract}
Продукты пероксидного окисления липидов образуются в местах повышения окислительного стресса, их накопление сопровождается возникновением атеротических повреждений. Большинство исследований проведенных до настоящего времени посвящены образованию и метаболизму окисленных липидов, в то же время очень мало данных об их биологиче-
\end{abstract}

Citation:

Gryvul, T.M., Veres Ye.M., Makukh Ye.M. (2016). The influnce of oxidation products of cholesterol ester on atherosclerosis development. Scientific Messenger LNUVMBT named after S.Z. Gzhytskyj, 18, 3(70), 49-56. 
ской активности и возможных патофизиологических функциях. В данном обзоре сделана попьтка проанализировать механизмы образования, метаболическую активность и пути превращения эфиров холестерола содержсащих ненасыщеннье жсиные кислоты, которые могут окисляться с образованием пероксидов. Последние способны восстанавливаться к соответствуюшим спиртам, которые могут окисляться к биологически-активным альдегидам вносящим значительный вклад у развитие прогрессирующих атеросклеротических повреждений.

Наибольшее количество эфиров холестерола содержится у $\beta$-липопротеинах, которые локализированы в гидрофобном ядре, но способны при этом окисляться быстрее, нежели фосфолипиды внешнего слоя. Большинство альдегидов образуемых при пероксидации эфиров холестерола - это девяти-, восьми-и пятиуглеродные соединения. Поскольку эфиры холестерола у $\beta$-липопротеинах образовань преимущественно линолевой кислотой, поэтому ее уровень оказался надежным тестом степени пероксидации этих эфиров.

Анализ стереоизомеров окисленных липидов выделенных из атерогенных бляшок свидетельствует о значительной роли энзима липооксигеназы в оксидативной модификации эфиров холестерола. Определенную роль у метаболизме холестерола играют и селенсодержащие энзимы, в частности: глутатионпероксидаза и тиоредоксинредуктаза. Получены также убедительные данные об участии в этих процессах и альдозоредуктазы.

Эфиры холестерола тормозят митотическую активность фактора роста атерогенных блямок, фактора роста фибробластов и $\beta 1$-антипролиферативную активность трансформирующего фактора росту.

Таким образом, оксидативная модификация липидов вообще и окисленных эфиров холестерола в частности является одной из причин развития прогрессирующих атеросклеротических повреждений, но к сожалению метаболический путь от липопротеиновой частиць до атеросклеротической бляики изучен недостаточно.

Ключевые слова: оксидация липидов, пероксидация эфиров холестерола, воспаление, атеросклероз.

\title{
The influnce of oxidation products of cholesterol ester on atherosclerosis development
}

\author{
T.M. Gryvul, Ye.M. Veres, Ye.M. Makukh \\ grytheo@gmail.com
}

\begin{abstract}
Lviv national university of veterinary medicine and biotechnologies named after S. Gzhytskyj, Pekarska Str., 50, Lviv, 79010, Ukraine
\end{abstract}

Products of per oxide lipid oxidation are produced in the place of increased oxidative stress and their accumulation leads to aterotic damage. Most of the investigations are still devoted to formation and oxidized lipid metabolism, but the data on their biological activity and possible pathophysiological functions are not many. In this review it was done an attempt to analyze the mechanisms of formation, metabolic activity and by transforming the cholesterol ester, which contain the unsaturated fatty acids, that may oxidize to form peroxides. The last are able to be restored to appropriate alcohols, which can be oxidized to biologically active aldehydes, which make a significant contribution to the development of progressive atherosclerotic lesions.

The most cholesterol esters are as a part of $\beta$-lipoproteins, localized in the hydrophobic core and in doing so are able to be oxidized hydro peroxides faster than the outer layer of phospholipids. Most of aldehydes, which are formed at per ester oxidationthese are nine-, eight-and five carbon compounds. Because of cholesterol esters in $\beta$-lipoprotein were formed mainly by linoleic acid, therefore its level was reliable test of per oxidation degree of these esters.

The analysis of stereoisomers of oxidized lipids, which were marked from atherogenic plaques, witnessed a significant contribution of the enzyme lipooxi genesis in oxidative modification of cholesterol esters. Selenium containing enzymes play an important role in the metabolism of cholesterol hydroxides esters, in particular: glutathionereductase and tioredoxinereductase. It was also obtained the convincing data on the participation of aldosereductase in these processes.

Esther of cholesterol inhibit the mitotic activity of growth factor of atherogenic plaques, fibroblast growth factor and the $\beta 1-$ antiproliferative activity of transforming growth factor.

Hence, oxidative modification of lipids in general, oxidized of cholesterol esters and in particular, is one of the causes of progressive development of atherosclerotic damages, Although metabolic pathway of lipoprotein particles to the atherosclerotic plaque is search enough.

Key words: lipid oxidation, cholesterol ester hydroperoxides, inflammation, atherosclerosis.

Оксидативна модифікація ліпідів проявляється у клітинному метаболізмі як у нормі, так і за патології (атеросклерозі, онкозахворюваннях, ревматоїдному артриті, діабеті та інших захворюваннях). Зокрема, при атеросклерозі порушується обмін різних класів ліпопротеїнів. Виходячи з сучасних знань про обмін ліпідів можна сказати, що без атерогенних ліпопротеїнів не може бути атеросклерозу.

Ліпопротеїни - складні білки, простетичною групою в яких виступає ліпідний компонент. Найчастіше простетичною групою є триацилгліцериди, фосфогліцериди та холестерол. В організмі ліпопротеїни $є$ транспортним засобом для перенесення кров'ю нерозчинних i малорозчинних у воді триацилгліце- ридівв, холестеролу та його естерів. Ліпопротеїни відрізняться між собою масовою часткою протеїну та простетичної групи.

Серед ліпопротеїнів розрізняють декілька класів, а саме: $\alpha$-ліпопротеїни - ліпопротеїни високої густини (ЛПВГ), $\beta$-ліпопротеїни - ліпопротеїни низької густини (ЛПНГ) і пре- $\beta$-ліпопротеїни - ліпопротеїни дуже низької густини (ЛПДНГ) і хіломікрони (XМ). Неоднаковим $\epsilon$ склад ліпідів простетичної групи ліпопротеїнів. Так, у хіломікронах переважають тригліцериди, а у $\alpha-, \beta-i$ пре- $\beta$-ліпопротеїнах переважають холестерол і фосфоліпіди.

Атеросклероз і пов'язані 3 ним захворювання, протікають при значному підвищенні в плазмі крові 
$\beta$-ліпопротеїнів і пре- $\beta$-ліпопротеїнів. Правда, ініціюючим фактором при цьому виступають незначні пошкодження ендотелію кровоносних судин зумовлені підвищенням тиску крові, запальними процесами, порушенням згортання крові та дією токсинів. Відомо, що хіломікрони не можуть проникати в середину судинної стінки із-за своїх великих розмірів, а $\beta$-ліпопротеїни мають таку здатність. Протягом атеросклерозу вони проникають в інтиму клітин гладких м'язів і крові, накопичуються під ендотелієм судинної стінки і стають атерогенними (Berliner and Heinecke, 1996; Lusis, 2000; Glass and Witztum, 2001). Різні форми окиснених ліпідів, включаючи окиснені продукти естерів холестеролу можуть викликати атеросклеротичні пошкодження, оскільки проявляють різноманітну біологічну активність.

Ініціюючим і вирішальним фактором в патогенезі атерогенезу є адгезія моноцитів в ендотелії, які склеюються і мігрують у субтеліальний простір і перетворюються у зрілі макрофаги (Lusis, 2000; Glass and Witztum, 2001). Останні можуть окиснювати ЛПНГ через відповідні рецептори і здатні акумулювати ліпіди, зокрема естери холестеролу. В некротичному ядрі атеросклеротичного пошкодження, спричиненого цими клітинами, може звільнятися їх вмістиме, тобто не тільки окиснені естери холестеролу, а й інші окиснені продукти ліпідів, які акумулюються в позаклітинному просторі. В даний час відомостей про патофізіологічну роль цих окиснених ліпідних продуктів явно недостатньо. У плазмі людини і пацюка виявлені гідропероксиди естерів холестеролу, в той же час продуктів ліпопероксидації фосфоліпідів не виявлено.

Відомо, що особливо схильні до оксидативної модифікації поліненасичені жирні кислоти. Продукти пероксидації ліпідів ведуть до утворення гідропероксидів ліпідів (Porter et al., 1995), які внаслідок розриву міжкарбонових зв'язків утворюють коротколанцюгові неестерифіковані (Esterbauer et al., 1978) та естерифіковані альдегіди, яких називають коровими (core) тобто, альдегіди ядра (Kamido et al., 1992, 1993, 1995). Одначе, у більшості проведених досліджень вивчали оксидативну модифікацію естерів холестеролу, а пероксиди ліпідів визначали як індикатори пероксидації ліпідів. Відновлення продуктів пероксидації ліпідів, альдегідів, веде до утворення відповідних спиртів, які, як відомо, є біологічно неактивними.

Встановлено, що естери холестеролу локалізуються у гідрофобному ядрі

ЛПНГ - частинок. В окремих дослідженнях було виявлено, що ці компоненти окиснюються до гідропероксидів швидше, ніж поліненасичені фосфоліпіди в зовнішньому моношарі ЛПНГ (Noguchi et al., 1991; Stocker et al., 1991; Noguchi et al., 1993), тоді як інші дослідники не дотримуються такої думки, бо вважають, що спочатку проходить окиснення частинок ЛПНГ зовнішнього шару (Meyer et al., 1996).

Недавно проведеними дослідженнями in vitro встановлено, що при окисненні ЛПНГ, ЛПВГ i виділених естерів холестеролу з використанням солей Купруму або гідропероксид трет-бутилу утворюються гідропероксиди естерів холестеролу так само ак- тивно як і естери холестеролу ядерних альдегідів, що містять естерифіковані стероли, оксистероли та продукти розпаду окиснених жирних кислот $з$ карбонільними групами (Kamido et al., 1992, 1993).

Більшість альдегідів, що утворилися при пероксидації естерів холестеролу - це дев'яти- восьми- та п'ятикарбонові сполуки, а саме: 9-оксонаноїл, 8оксонаноїл, 5-оксовалероїл, естери холестеролу і 7кетохолестеролу. Альдегіди ядра складають всього 12\% від кількості естерів лінолеату та арахідоноату (Kamido et al., 1995). Естери холестеролу, які є в складі ЛПНГ при окисненні за допомогою пероксидрадикалів та ліпоксигенази соєвих бобів в присутності $\alpha$-токоферолу перетворюються до гідропероксидів i гідроксидів естерів холестеролу (Garner et al., 1998), а при окисненні за допомогою солей $\mathrm{Cu}$ та ферилміоглобіну перетворюються до арахідонату-, лінолеату- і олеату холестеролу та вільного холестеролу (Brown et al., 1996).

При дослідженні кислот у складу естерів холестеролу у ЛПНГ встановлено, що переважаючою кислотою є лінолева, яка виявилась добрим індикатором пероксидації ліпідів ЛПНГ. Крім вищезазначених окиснювачів, для окиснення ЛПНГ використовують ще 2,2-азо-біс (2-амідинопропан) дигідрохлорид. Використання цього окиснювача спричиняє утворення стереоізомерів гідропероксидів холестерид лінолеату. При наявності $\alpha$-токоферолу 9- і 13гідропероксиди холестерол лінолеату 3 транс-цис диенових кон'югатів починають перетворюватись у транс-транс форми (Kenar et al., 1996).

Незважаючи на окремі дослідження про роль ліпоксигенази в модифікації холестеридів під час окиснення ЛПНГ, окремі автори (Belkner et al., 1991, 1993, Kuhn et al., 1994; Belkner et al., 1998, 1999) вважають, що твердження про те, що окиснення більшості естерів холестеролу проходить опосередковано за участю вільних радикалів, є недостатньо обгрунтованим (Mashima et al., 2000). Інкубація ЛПНГ з клітинами 3 надекспресією ензиму 15-ліпоксигенази призводить до значного зростання гідропероксидів холестеридів і в той же час відмічено незначне підвищення гідропероксидів жирних кислот та фосфоліпідів (Ezaki et al., 1995). Подальшими дослідженнями було підтверджено, що 15-ліпоксигеназа ссавців найкраще окиснює холестериди ЛПНГ (Belkner et al., 1998). Виявилось, що ензиматичне окиснення вільних жирних кислот може передувати окисненню естерів холестеролу (Lass et al., 1996; Upston et al., 1996), а зростання вмісту вільних жирних кислот у ЛПНГ полегшує каталітичне окиснення естерів холестеролу індуковане 15-ліпоксигеназою (Upston et al., 1997). Аналіз R i S стереоізомерів окиснених ліпідів ізольованих $з$ атеросклеротичних бляшок людини засвідчив значний вклад ліпоксигенази в оксидативну модифікацію естерів холестеролу, що вказує, очевидно, на важливу роль цього ензиму в патогенезі атеросклеpoзy (Kuhn et al., 1992; 1994; Folcik et al., 1995).

Вивчається також роль лецитин-холестерол-ацилтрасферази (ЛХАТ) в окисненні естерів холестеролу 3 моменту розпаду гідропероксидів фосфоліпідів, внаслідок чого утворюються окиснені естери холестеро- 
лу. Але ця реакція гальмується інгібіторами ЛХАТ. Варто зазначити, що ЛХАТ каталізуе зовнішньоклітинну естерифікацію холестеролу, тобто перенесення ацильного залишку з 2-положення фосфатидилхоліну на гідроксильну групу холестеролу. Якщо вона бере участь в окисненні естерів холестеролу, то, очевидно, проявляє i окидазну активність. I насамкінець, слід зазначити, що процеси метаболізму ЛПНГ і ЛПВГ мають свої особливості, зокрема перенесення гідроксидів жирних кислот до холестеролу спостерігається тільки у ЛПВГ і відсутге у ЛПНГ (Nagata et al., 1996).

Гідропероксиди ліпідів відносно легко піддаються розпаду з утворенням високореактивних радикалів декількох видів - пероксил, алкоксил, та гідропероксил, які можуть ініціювати оксидативні процеси, що є шкідливими для процесів обміну. Отже, ензиматичне відновлення пероксидів ліпідів до відповідних гідроксидів може репрезентувати важливий захисний механізм в місцях зростання оксидатиного стресу.

У плазмі крові людини і щурів наявні гідропероксиди естерів холестеролу, тоді як гідропероксиди фосфоліпідів не виявлені. Ймовірно, це зумовлено тим, що в плазмі крові функціонують ензиматичні та неензиматичні системи, які відновлюють гідроксиди у плазмі до гідропероксидів естерів холестеролу 3 участю лецитин-холестерол-ацилтрансферази у ЛПВГ (Yamamoto and Niki, 1989; Nagata et al., 1996). Дослідження плазми крові здорових голодуючих волонтерів підтвердили, що більше окиснених корових ліпідів ліпопротеїнів були у складі ЛПВГ тоді як пероксиди утворювались 3 ліпопротеїнів у складі ЛПНГ i були на відносно низькому рівні (Bowry et al., 1992). Ця переважаюча акумуляція гідропероксидів ліпідів у складі ЛПВГ пояснюється втратою антиоксидантів порівняно з ЛПНГ. Гідроксиди естерів холестеролу, які асоційовані у ЛПНГ можуть бути перенесені до ЛПВГ, тобто між ЛПНГ і ЛПВГ відбувається обмін окремими компонентами (Christison et al., 1995). Однак, для цього потрібні подальші дослідження.

Гідропероксиди естерів холестеролу асоційованих 3 ЛПВГ, швидко відновлюються до відповідних гідроксидів, ймовірно, за участю глютатіонпероксидази (Sattler et al., 1995), важливу роль у цих процесах відіграє окиснення специфічних залишків в апопротеїнах A1 i A11 (Garner et al., 1989).

ЛПВГ є не тільки носіями значної кількості гідропероксидів естерів холестеролу, але вони здатні ще і до пролонгованого зниження загальної кількості продуктів пероксидації ліпідів, які генеровані ЛПНГ. На жаль, механізми цього процесу все ще не встановлені i пояснити їх звичайною недостатністю антиоксидантів у складі ЛПНГ видається не зовсім коректним, хоча, як вважають деякі автори, у цьому процесі можуть бути задіяні ензиматичні системи (Mackness and Durrington, 1995).

Один $з$ таких зв'язаних з ЛПВГ ензимів - параоксоназа-1 (ПОН-1), розкладає не тільки окиснені фосфоліпіди, але і гідропероксиди естерів холестеролу, тобто володіє широкою субстратною специфічністю (Aviram et al., 1998), хоча точний механізм цього процесу до сьогодні ще не зовсім зрозумілий (Laplaud et al., 1998). Виявилось, що цей ензим активний in vitro, оскільки гідропероксиди і пероксиди естерів холестеролу виділені з атеросклеротичних бляшок людини розкладаються під дією параоксонази-1 (Aviram et al., 2000).

Також встановлно, що інший НАДФ-залежний ензим - альдозоредуктаза відновлює ядерні альдегіди у складі фосфоліпідів (Srivastava et al., 2001). Таким чином, альдозоредуктаза може бути одним із ензиматичних механізмів системи захисту клітини від дії токсичних сполук різної хімічної природи взагалі, i, можливо, токсичних продуктів окиснення естерів холестеролу зокрема (Srivastava et al., 1998).

Макрофаги та їх похідні «навантажені» вільним холестеролом та його естерами є характерною ознакою атеросклеротичних бляшок. Таке “навантаження” макрофагів окисненими ЛПНГ веде до акумуляції окиснених естерів холестеролу в лізосомах. Виявилось, що інактивація та детоксикація гідропероксидів холестеролу може проходити за участю і позаклітинних макрофагів, які виділяють продукти для відновлення гідропероксидів ліпідів (Kritharides et al., 1998; Brown et al., 2000).

Було встановлено, що продуктами окиснення гідропероксидів холестерол лінолеату $є$ відповідні гідроксиди, і частково кето-октадекадиеноати (Baoutina et al., 2000). Крім того, окиснені продукти естерів холестеролу, як виявилось, здатні до утворення комплексів з білками сироватки крові. Зокрема, один 3 продуктів пероксидації естерів холестеролу, ймовірно 9-октонаноїл взаємодіє з білками через аміногрупу лізину (Норpe et al., 1997). Такі ліпопротеїнові комплекси стають більш стабільними, а окиснені холестеролові естери більш стійкими до розпаду. Крім того, виявлено, що окиснені форми естерів холестеролу були менш чутливими до гідролітичного розпаду за участю макрофагів лізосом порівняно 3 неокисненими естерами холестеролу (Норpe et al., 1997; Brown et al., 2000).

Встановлено, що окиснені ліпіди впливають на ензими обміну холестеролу, зокрема - гальмують активність нейтральної або кислої холестеролестерази (Maehira, 1994). 3 іншої сторони є повідомлення про те, що окиснені естери холестеролу є кращими і більш доступними субстратами для холестеролестерази i гормончутливої ліпази, порівняно 3 неокисненими естерами холестеролу (Belkner et al., 2000).

Серед ензимів причетних до відновлення гідропероксидів естерів холестеролу важливе значення мають селензалежні ензими. Зокрема глютатіонпероксидаза, яка має широку субстратну специфічність і здатна до відновлення гідропероксидів естерів холестеролу без попереднього гідролізу жирних кислот (Thomas et al., 1990; Sattler et al., 1994; Pushpa-Rekha et al., 1995). Інший селенвмісний ензим - тіоредоксинредуктаза відновлює з участю НАДФН гідропероксиди ліпідів до відповідних спиртів (Bjornstedt et al., 1995). Каталітичну активність проявляє також апопротеїн В, який відновлює пероксиди ліпідів та гідропероксиди естерів холестеролу (Mashima et al., 1999). Але, щоб ці твердження не були спекулятивними, тобто не знижували вкладу цих ензимів у знешкодження гідропе- 
роксидів потрібні подальші та більш глибокі дослідження у цьому напрямі.

Гідропероксиди ліпідів не накопичуються у плазмі крові тому, що ЛПВГ переносять їх у печінку, в якій гідропероксиди естерів холестеролу розкладаються гепатоцитами швидше, ніж неокиснені естери холестеролу (Sattler and Stocker, 1993). У гепатоцитах гідропероксиди ліпідів не виявляються, що може свідчити про їх інтенсивний розпад у цих клітинах. Подальші дослідження проведені на щурах показали, що знешкодження циркулюючих гідропероксидів і гідроксидів холестеридів, асоційованих з ЛПВГ ефективно і селективно здійснюється печінкою (Fluiter et al., 1996). Слід зазначити, що на даний час стає зрозумілою опосередкована роль печінки і зокрема паренхіматозних клітин, які спряжені з секрецією жовчі. Використовуючи метод перфузії печінки щура було встановлено, що окиснені естери холестеролу ефективніше переміщаються печінкою ніж неокиснені естери. Гідропероксиди естерів холестеролу у складі ЛПВГ швидко відновлювались, чого не відмічено 3 гідропероксидами естерів холестеролу асоційованих у складі ЛПНГ (Christison et al., 1996). Отже, ці дослідження свідчать ро центральну роль печінки в детоксикації циркулюючих гідропероксидів ліпідів ядра і стає зрозумілою подальша роль ЛПВГ у цьому процесі.

Встановлено, що концентрація продуктів окиснення естерів холестеролу у крові здорових організмів $\epsilon$ значно нижчою, ніж у пацієнтів 3 атеросклерозом (Thomas et al., 1994). Гідропероксиди естерів холестеролу у плазмі крові здорових людей виявляються тільки в наномолярних кількостях (Yamamoto and Niki, 1989). Аналіз розподілу стереоізомерів гідроксидів і гідропероксидів показав, що утворення цих окиснених ліпідних продуктів було більш опосередковано індукцією вільних радикалів, утворених при окисненні ліпідів, ніж ензиматичною модифікацією (Mashima et al., 2000). Це може свідчити про те, що окиснення ненасичених ліпідів $€$ нормальним фізіологічним процесом, який протікає у здорових людей. Зростання в плазмі вмісту гідропероксидів естерів холестеролу виявлені у пацієнтів, які страждають від субарахноїдальних геморагій та ішемічного паралічу. У цих дослідженнях зростання рівня гідроксидів естерів холестеролу були зв'язані зі зростанням смертельних випадків і корелювали з масштабами клінічних результатів, а це, на думку авторів, може означати, що вміст гідроксидів естерів холестеролу може бути використаний як прогностичний маркер ефективності терапевтичного втручання (Polidori et al., 1997, 1998).

Акумуляція пероксидів ліпідів в атеросклеротичних бляшках веде до розвитку стабільного прогресуючого пошкодження (Felton et al., 1997; Nishi et al., 2002). Однак, встановлення біологічної ролі продуктів пероксидації ліпідів та їх метаболітів в деталях ще не вивчено. Аналіз часозалежних змін вмісту ліпідів в аорті мишей, що одержували раціон 3 високим вмістом ліпідів, за відсутності апопротеїну Е показав, що в аорті зростав вміст гідропероксидів естерів холестеролу та прогресували атеросклеротичні зміни
(Letters et al., 1999). У дослідженнях $з$ пошкодженнями аорти встановлено, що акумуляція неокиснених ліпідів передує накопиченню гідропероксидів естерів холестеролу (Suarna et al., 1995; Upston et al., 2002). Досліди проведені з гомогенатами атеросклеротичних бляшок показали, що вони містять велику кількість окиснених ліпідів, зокрема, майже $30 \%$ жирних кислот і половина холестерил лінолеату були в окисненій формі (Suarna et al., 1995). При цьому більш окисненими у бляшках виявилися естери холестерол лінолеату з середнім вмістом холестеролу приблизно 0.50 моль/моль холестеролу (Karten et al., 1998). Дослідження показали, що у поражених ділянках холестерол лінолеат присутній у вигляді різних окиснених форм $(2,0-5,0 \%)$ гідропероксидів або гідроксидів (Niu et al., 1999). В атеросклеротичних бляшках людини 9-оксонаноїл холестеролу був виявлений як один 3 найбільш окиснених похідних холестеролу (Kamido et al., 1992, 1995; Hoppe et al., 1997; Karten et al., 1998, 1999). В досліджуваних бляшках концентрація 9-оксонаноїлу в середньому складала 29 моль/моль холестеролу (Karten et al., 1998).

Таким чином, ці дані свідчать про те, що вміст окиснених похідних естерів холестеролу $є$ вищим у місцях ураження, ніж у нормальних тканинах. На даний час $є$ тільки поодинокі дані про вплив окиснених продуктів естерів холестеролу на фізіологічні і особливо на патологічні процеси в організмі людини. Так, інкубування макрофагів з естерами холестеролу спричиняє пошкодження клітин, а внесення антиоксидантів в інкубаційне середовище запобігає цьому процесові (Reid et al., 1992). Як виявилось ця токсичність зумовлена зростанням ненасиченості жирних кислот та початковими явищами некрозу макрофагів в атеросклеротичних бляшках. (Hardwick et al., 1997). Крім того, 9 і 13-гідроксильовані похідні естерів лінолеату холестеролу виявились інгібіторами мітогенної активності фактору росту атерогенних бляшок, основного фактора росту фібробластів i $\beta 1-$ антипроліферативної активності трансформуючого фактора росту, але не впливають на мітогенну активність епідермального фактора росту.

Окремі автори вважають, що цей модулюючий вплив на різні тканинні фактори може відігравати важливу роль під час запальних атеросклеротичних процесів (Van Heek et al., 1998). Альдегіди ядра взаємодіючи 3 аміногрупою лізину утворюють Шифові основи не тільки з апопротеїном В, але й іншими білками (Steinbrecher et al., 1984, 1989), а це впливає на їх біологічні функції. Похідні продуктів окиснення лінолеату холестеролу стимулюють ендотеліальні клітини, які специфічно зв'язують моноцити (Huber et al., 2002). Крім, 9-оксонанонеїлу - продукту окиснення естерів холестеролу ідентифіковано ще цілий ряд інших біологічно-активних метаболітів гідропероксидів лінолеату холестеролу, хоча не всі з них були біологічно активні. Однак такі естери гідропероксидів холестеролу очевидно певним чином впливають на структуру ядерних альдегідів холестеролу, що може породжувати спекулятивні твердження про біологічну активність гідропероксидів естерів ліноле- 
ату холестеролу, які можуть вносити свій вклад у фрагментацію продуктів подальшої оксидації.

За біологічну активність окисненого холестерол лінолеату відповідають. функціональні групи, бо відновлення його і гідропероксидів холестерол лінолеату боргідридом натрію призводить до зниження їх біологічної активності. Це, очевидно, зв'язано зі зниженням індукції адгезії моноцитів (Huber et al., 2002). Крім того, відновлення 9-оксонаноїл холестеролу усуває його здатність до індукції адгезії моноцитів, вказуючи на те, що відновлення альдегідів $є$ наслідком зниження їх активності.

Отже, оксидативна модифікація ліпідів взагалі, та окиснених естерів холестеролу зокрема, $є$ однією 3 причин розвитку прогресуючих атеросклеротичних пошкоджень, хоча метаболічний шлях від ліпопротеїнових частинок до атеросклеротичної бляшки вивчений недостатньо.

\section{Бібліографічні посилання}

Berliner, J.A., Heinecke, J.W. (1996). The role of oxidized lipoproteins in atherogenesis. Free Radic. Biol. Med. 20, 707-727.

Lusis, A.J. (2000). Atherosclerosis. Nature. 407, 233 241.

Glass, C.K., Witztum, J.L. (2001). Atherosclerosis, the road ahead. Cell. 104, 503-516.

Porter, N.A., Caldwell, S.E., Mills, K.A. (1995). Mechanisms of free radical oxidation of unsaturated lipids. Lipids. 30, 277-290.

Esterbauer, H., Jurgens, G., Quehenberger, O. et al. (1978). Autoxidation of human low density lipoprotein: loss of polyunsaturated fatty acids and vitamin $\mathrm{E}$ and generation of aldehydes. J. Lipid Res. 28, 495509.

Kamido, H., Kuksis, A., Marai, L. et al. (1992). Identification of cholesterol-bound aldehydes in copperoxidized low density lipoprotein. FEBS Lett. 304, 269-272.

Kamido, H., Kuksis, A., Marai, L. et al. (1993) Identification of core aldehydes among in vitro peroxidation products of cholesteryl esters. Lipids. 28, 331-336.

Kamido, H., Kuksis, A., Marai, L.et al. (1995). Lipid ester-bound aldehydes among copper-catalyzed peroxidation products of human plasma lipoproteins. J. Lipid Res. 36, 1876-1886.

Stocker, R., Bowry, V.W., Frei, B. (1991). Ubiquinol-10 protects human low density lipoprotein more efficiently against lipid peroxidation than does alphatocopherol. Proc. Natl. Acad. Sci. USA. 88, 16461650.

Noguchi, N., Gotoh, N., Niki, E. (1993). Dynamics of the oxidation of low density lipoprotein induced by free radicals. Biochim. Biophys. Acta. 1168, 348-357.

Noguchi, N., Numano, R., Kaneda, H.et al. (1998). Oxidation of lipids in low density lipoprotein particles Free Radic. Res. 29, 43-52.

Meyer, D.F., Nealis, A.S., Macphee, C.H.et al. (1996). Time-course studies by synchrotron $\mathrm{X}$-ray solution scattering of the structure of human low-density lipoprotein during $\mathrm{Cu}(2+)$-induced oxidation in relation to changes in lipid composition. Biochem. J. 319 (Pt 1), 217-227.

Garner, B., Waldeck, A.R., Witting, P.K.et al. (1998). Oxidation of high density lipoproteins. II. Evidence for direct reduction of lipid hydroperoxides by methionine residues of apolipoproteins A1 and A11. J. Biol. Chem. 273, 6088-6095.

Garner, B., Witting, P.K., Waldeck, A.R.et al. (1998). Oxidation of high density lipoproteins.I. Formation of methionine sulfoxide in apolipoproteins AI and All is an early event that accompanies lipid peroxidation and can be enhanced by alpha-tocopherol. J. Biol. Chem. 273, 6080-6087.

Brown, A.J., Dean, R.T., Jessup, W. (1996). Free and esterified oxysterol: formation during copperoxidation of low density lipoprotein and uptake by macrophages. J. Lipid Res. 37, 320-335.

Kenar, J.A., Havrilla, CM., Porter, N.A.et al. (1996). Identification and quantification of regioisomeric cholesteryl linoleate hydroperoxides in oxidized human low density lipoprotein and high density lipoprotein. Chem. Res. Toxicol. 9, 737-744.

Mashima, R., Onodera, K., Yamamoto, Y. (2000). Regioisomeric distribution of cholesteryl linoleate hydroperoxides and hydroxides in plasma from healthy humans provides evidence for free radical-mediated lipid peroxidation in vivo. J. Lipid Res.41, 109-115.

Belkner, J., Wiesner, R., Kuhn, H.et al. (1991). The oxygenation of cholesterol esters by the reticulocyte lipoxygenase. FEBS Lett. 279, 110-114.

Belkner, J., Wiesner, R., Rathman, J.et al. (1993). Oxygenation of lipoproteins by mammalian lipoxygenases. Eur. J. Biochem. 213, 251-261.

Kuhn, H., Belkner, J., Suzuki, H.et al. (1994). Oxidative modification of human lipoproteins by lipoxygenases of different positional specificities. J. Lipid Res. 35, 1749-1759.

Belkner, J., Stender, H., Kuhn, H. (1997). Lipoxygenase preferentially oxygenates a subfraction of human low density lipoprotein. Adv. Exp. Med. Biol. 407, 4654469.

Belkner, J., Stender, H., Kuhn, H. (1998). The rabbit 15lipoxygenase preferentially oxygenates LDL cholesterol esters, and this reaction does not require vitamin E. J. Biol. Chem. 273, 23225-23232.

Ezaki, M., Witztum, J.L., Steinberg, D. (1995). Lipoperoxides in LDL incubated with fibroblasts that overexpress 15-lipoxygenase. J. Lipid Res. 36, 1996-2004.

Lass, A., Belkner, J., Esterbauer, H. et al. (1996). Lipoxygenase treatment render low-density lipoprotein susceptible to $\mathrm{Cu}^{2+}$-catalysed oxidation. Biochem. J. 314 (Pt 2), 577-585.

Upston, J.M., Neuzil, J., Stacker, R. (1996). Oxidation of LDL by recombinant human 15-lipoxygenase: evidence for alpha-tocopherol-dependent oxidation of esterified core and surface lipids. J. Lipid Res. 37, 2650- 2661.

Upston, J.M., Neuzil, J., Witting, P.K. et al. (1997). Oxidation of free fatty acids in low density lipoprotein by 15-lipoxygenase stimulates nonenzymic, alphatocophcrol-mediated peroxidation of cholesteryl esters. J. Biol. Chem. 272, 30067-30074. 
Folcik, V.A., Nivar-Aristy, R.A., Krajewski, L.P. et al. (1995). Lipoxygenase contributes to the oxidation of lipids in human atherosclerotic plaques. J. Clin. Invest. 96, 504-510.

Kuhn, H., Belkner, J., Wiesner, R. et al. (1992). Structure elucidation of oxygenated lipids in human atherosclerotic lesions. Eicosanoids. 5, 17-22.

Kuhn, H., Belkner, J., Zaiss, S.et al. (1994). Involvement of 15-lipoxygenase in early stages of atherogenesis. J. Exp. Med. 179, 1903-1911.

Nagata, Y., Yamamoto, Y., Niki, E. (1996). Reaction of phosphatidylcholine hydroperoxide in human plasma: the role of peroxidase and lecithin:cholesterol acyltransferase. Arch. Biochem. Biophys. 329, 24-30.

Yamamoto, Y., Niki, E. (1989). Presence of cholesteryl ester hydroperoxide in human blood plasma. Biochem. Biophys. Res. Commun. 165, 988-993.

Bowry, V.W., Stanley, K.K., Stacker, R. (1992). High density lipoprotein is the major carrier of lipid hydroperoxides in human blood plasma from fasting donors. Proc. Natl. Acad. Sci. USA. 89, 10316-10320.

Christison, J.K., Rye, K.A., Stocker, R. (1995). Exchange of oxidized cholesteryl linoleate between LDL and HDL mediated by cholesteryl ester transfer protein. J. Lipid Res. 36, 2017-2026.

Sattler, W., Christison, J., Stocker, R. (1995). Cholesterylester hydroperoxide reducing activity associated with isolated high- and low-density lipoproteins. Free Radic. Biol. Med. 18, 421-429.

Mackness, M.I., Durrington P.N. (1995). HDL, its enzymes and its potential to influence lipid peroxidation. Atherosclerosis. 115, 243-253.

Aviram, M., Rosenblat, M., Bisgaier, C.L. et al. (1998) Paraoxonase inhibits high-density lipoprotein oxidation and preserves its functions. A possible peroxidative role for paraoxonase. J. Clin. Invest. 101, 15811590.

Laplaud, P.M., Dantoine, T., Chapman, M.J. (1998). Paraoxonase as a risk marker for cardiovascular disease: facts and hypotheses. Clin. Chem. Lab. Med. 36, 431-441.

Aviram, M., Hardak, E., Vaya, J. et al. (2000). Human serum paraoxonases (PON1) Q and R selectively decrease lipid peroxides in human coronary and carotid atherosclerotic lesions: PON1 esterase and peroxidase-like activities. Circulation. 101, 2510-2517

Srivastava, S., Liu, S.Q., Conklin, D.J. et al. (2001). Involvement of aldose reductase in the metabolism of atherogenic aldehydes. Chemico-Biol. Interact. 130, $563-571$.

Srivastava, S., Chandra, A., Wang, L.P. (1998). Metabolism of the lipid peroxidation product, 4-hydroxytrans-2nonenal, in isolated perfused rat heart. J. Biol. Chem. 273, 10893-10900.

Kritharides, L., Upston, J., Jessup, W. et al. (1998). Accumulation and metabolism of low density lipoprotein-derived cholesteryl linoleate hydroperoxide and hydroxide by macrophages. J. Lipid Res. 39, 2394 2405.

Brown, A.J., Mander, E.L., Gelissen, I.C.et al. (2000). Cholesterol and oxysterol metabolism and subcellular distribution in macrophage foam cells. Accumulation of oxidized esters in lysosomes. J. Lipid Res. 41, 226237.

Baoutina, A., Dean, R.T., Jessup, W. (2000). Macrophages can decrease the level of cholesteryl ester hydroperoxides in low density lipoprotein. J. Biol. Chem. 275, 1635-1644.

Hoppe, G., Ravandi, A., Herrera, D. et al. (1997). Oxidation products of cholesteryl linoleate are resistant to hydrolysis in macrophages, form complexes with proteins, and are present in human atherosclerotic lesions. J. Lipid Res. 38, 1347-1360.

Maehira, F. (1994). Inhibitory effect of lipid hydroperoxide on cholesteryl esterases. Biochem. Mol. Biol. Int. 32, 221-231.

Belkner, J., Stender, H., Holzhutter, H.G. et al. (2000). Macrophage cholesteryl ester hydrolases and hormone-sensitive lipase prefer specifically oxidized cholesteryl esters as substrates over their nonoxidized counterparts. Biochem. J. 352 (Pt 1), 125133.

Thomas, J.P., Geiger, P.G., Maiorino, M.et al. (1990). Enzymatic reduction of phospholipid and cholesterol hydroperoxides in artificial bilaycrs and lipoproteins. Biochim. Biophys. Acta. 1045, 252-260.

Sattler, W., Maiorino, M., Stocker, R. (1994). Reduction of HDL- and LDL-associated cholesterylester and phospholipid hydroperoxides by phospholipid hydroperoxide glutathione peroxidase and Ebselen (PZ 51). Arch. Biochem. Biophys. 309, 214-221.

Pushpa-Rekha, T.R., Burdsall, A.L., Oleksa, L.M. et al. (1995). Rat phospholipid-hydroperoxide glutathione peroxidase. cDNA cloning and identification of multiple transcription and translation start sites. J. Biol. Chem. 270, 26993-26999.

Bjornstedt, M., Hamberg, M., Kumar, S. et al. (1995). Human thioredoxin reductase directly reduces lipid hydroperoxides by NADPH and selenocystine strongly stimulates the reaction via catalytically generated selenols. J. Biol. Chem. 270, 11761-11764.

Mashima, R., Yoshimura, S., Yamamoto, Y. (1999). Reduction of lipid hydroperoxides by apolipoprotein B100. Biochem. Biophys. Res. Commun. 259, 185-189.

Sattler, W., Stocker, R. (1993). Greater selective uptake by Hep G2 cells of high-density lipoprotein cholesteryl ester hydroperoxides than of unoxidized cholesteryl esters. Biochem. J. 294(3), 771-778.

Fluiter, K., Vietsch, H., Biessen, E.A. et al. (1996). Increased selective uptake in vivo and in vitro of oxidized cholesteryl esters from high-density lipoprotein by rat liver parenchymal cells. Biochem. J. 319 (Pt 2), 471-476

Christison, J., Karjalainen, A., Brauman, J. et al. (1996). Rapid reduction and removal of HDL- but not LDLassociated cholesteryl ester hydroperoxides by rat liver perfused in situ. Biochem. J. 314 (3), 739-742.

Thomas, J.P., Kalyanaraman, B., Girotti, A.W. (1994). Involvement of preexisting lipid hydroperoxides in $\mathrm{Cu}(2+)$-stimulated oxidation of low-density lipoprotein. Arch. Biochem. Biophys. 315, 244-254.

Polidori, M.C., Frei, B., Rordorf, G. et al. (1997). Increased levels of plasma cholesteryl ester hydroperox- 
ides in patients with subarachnoid hemorrhage. Free Radic. Biol. Med. 23, 762-767.

Polidori, M.C., Frei, B., Cherubim, A. et al. (1998). Increased plasma levels of lipid hydroperoxides in patients with ischemic stroke. Free Radic. Biol. Med. 25, $561-567$.

Nishi, K., Uno, M., Fukuzawa, K.et al. (2002). Clinicopathological significance of lipid peroxidation in carotid plaques. Atherosclerosis. 160, 289-296.

Felton, C.V., Crook, D., Davies, M.J. et al. (1997). Relation of plaque lipid composition and morphology to the stability of human aortic plaques. Arterioscler. Thromb. Vase. Biol. 17, 1337-1345.

Letters, J.M., Witting, P.K., Christison, J.K. et al. (1999). Time-dependent changes to lipids and antioxidants in plasma and aortas of apolipoprotein E knockout mice. J. Lipid Res. 40, 1104-1112.

Suarna, C., Dean, R.T., May, J. et al. (1995). Human atherosclerotic plaque contains both oxidized lipids and relatively large amounts of alpha-tocopherol and ascorbate. Arterioscler. Thromb. Vase. Biol. 15, 1616-1624.

Upston, J.M., Tcrentis, A.C., Morris, K. et al. (2002). Oxidized lipid accumulates in the presence of alphatocopherol in atherosclerosis. Biochem. J. 363, 753760.

Karten, B., Boechzelt, H., Abuja, P.M. et al. (1998). Femtomole analysis of 9-oxononanoyl cholesterol by high performance liquid chromatography. J. Lipid Res. 39, 1508-1519.

Niu, X., Zammit, V., Upston, J.M. et al. (1999). Coexistence of oxidized lipids and alpha-tocopherol in all lipoprotein density fractions isolated from advanced human atherosclerotic plaques. Arterioscler. Thromb. Vase. Biol. 19, 1708-1718.

Karten, B., Boechzelt, H., Abuja, P.M. et al. (1999). Macrophage-enhanced formation of cholesteryl ester-core aldehydes during oxidation of low density lipoprotein. J. Lipid Res. 40, 1240-1253.

Reid, V.C., Brabbs, C.E., Mitchinson, M.J. (1992). Cellular damage in mouse peritoneal macrophages exposed to cholesteryl linoleate. Atherosclerosis. 92, 251-260.

Hardwick, S.J., Carpenter, K.L., Law, N.S. et al. (1997). Toxicity of polyunsaturated fatty acid esters for human monocyte-macrofages: the anomalous behavior of cholesterol linoleate. Free Radic. Res. 26, 351-362.

Van, Heek M., Schmitt, D., Toren, P. et al. (1998). Cholesteryl hydroperoxyoctadecadienoate from oxidized low density lipoprotein inactivates platelet-derived growth factor. J. Biol. Chem. 273, 19405-19410.

Steinbrecher, U.P., Parthasarathy, S., Leake, D.S. et al. (1984). Modification of low density lipoprotein by endothelial cells involves lipid peroxidation and degradation of low density lipoprotein phospholipids. Proc. Natl. Acad. Sci. USA. 81, 3883-3887.

Steinbrecher, U.P., Lougheed, M., Kwan, W.C. et al. (1989). Recognition of oxidized low density lipoprotein by the scavenger receptor of macrophages results from derivatization of apolipoprotein B by products of fatty acid peroxidation. J. Biol. Chem. 264, 1521615223.

Huber, J., Boechzelt, H., Karten, B. et al. (2002). Oxidized cholesteryl linoleates stimulate endothelial cells to bind monocytes via the extracellular signalregulated kinase 1/2 pathway 1 . Arterioscler. Thromb. Vase. Biol. 22, 581-586.

Стаття надійшла до редакиії 3.10.2016 